\title{
EMPOWERING THE DOKRA ARTISANS THROUGH THE ACCESSIBILITY OF FINANCIAL RESOURCES FOR SURVIVAL OF THEIR INDIGENOUS TECHNOLOGY - A STUDY OF WEST BENGAL, INDIA
} SRIPARNA GUHA ${ }^{1}$, DR ARUN BANERJEE ${ }^{2} \&$ DR ANIRBAN MANDAL ${ }^{3}$

${ }^{I}$ Research Scholar \& Assistant Professor, Department of Managmeent, Brainware University, India

${ }^{2}$ Adjunct Professor, Department of Managmeent, Brainware University, India

${ }^{3}$ Associate Professor, Department of Management, Brainware University, India

\begin{abstract}
Handicraft industries that continue to play an significant role in rural industries in the survival and development of rural people from developing countries, such as India. Indigenous enterprises that have a clear connection with indigenous territory depend predominantly on local capital and give the rural population employment. The art of casting with wax lost technology, also known as Dokra art, is an old art in India and seems to have existed since the earliest days of settled culture in the subcontinent in an uninterrupted tradition. The ancient Dokra art craft of Dariapur village of Burdwan district and Bikana village of Bankura district of West Bengal (India) is not an exception of this concept. It is very difficult to maintain this ancient Dokra art and design on the market in a competitive environment today, with the fashion and luxury industry taking maximum share. But only the love and admiration of these craftsmen for their work make comparison with modern society possible. The paper attempts, by illustrating the numerous problems associated with this craft, to research the subsistence and socioeconomic conditions of Dokra workers from those two villages, with the aim of preserving their heritage in the future and concentrates on the accessibility of financial resources so that they can sustain a proper livelihood.

KEYWORDS: Indigenous Industry, Dokra Art, Heritage, Financial Resources, Socio-Economic Condition
\end{abstract}

Received: Jun 08, 2020; Accepted: Jun 28, 2020; Published: Sep 12, 2020; Paper Id.: IJMPERDJUN20201185

\section{INTRODUCTION}

As a result of changing preferences and trends and the growing cost of raw materials, Dokra is gradually becoming an iconic craft (Mrittika Foundation, 2014)1. "The Dokra Artisans from Bankura and Dariapur, West Bengal: A case study of technological change and knowledge Archive in progress”, drawn up by David Smith and Rajesh Kochhar, are significant works based on the field survey research conducted in the Bikna and Dariapur artisans's communities of Bankura. Through this thesis, a comprehensive research has been carried out on technical advances through dokra and bell metalwork and its effect on the market life of craftsmen. However, there is no insight into the problems and prospects of their craft. This paper will discuss the accessibility of financial resources of the Dokra artisans by which they can sustain their livelihood.

The indigenous artisan is the indigenous people who build, run and grow new businesses for themselves.

\footnotetext{
${ }^{1}$ Mrittika Foundation (2014). http://www.mrittikafoundation.com, accessed on 09.05.2020
} 
The native population comprises three primary principles deriving from communities that historically had immigrated to one area and retaining distinctive cultural and social traditions, as well as structures that have been dominated by subsequent arrivals, both culturally, socially and economically (Kochhar, 2001). The businesses operated by these businessmen may be corporate, public or non-profit organisations and would like the benefits gained from a limited perspective of economic advantage for a single person to a broad view of many, social and economic gains for whole societies (Arthur, 1999). Therefore, self-employment and entrepreneurship are considered not only to achieve economic stability but also to bring about meaningful social change (Holt, 1997). Indigenous companies typically distinguish themselves in three basic fields from traditional businesses, where the management and autonomous goods and services support their citizens and processes to obtain a reciprocal combination of technological and cultural competences are informed by identity and tribal pride.

\section{LITERATURE REVIEW}

Indigenous knowledge is nothing but a traditional knowledge carrying by the indegenous people for thousand of year which is considered as unique for culture or societies and the cluster of the inhabitants are recognized by teir indigenous knowledge as artisan in the society (Grenier, 1998; Warren \& Rajasekaran, 1993). Studies have hypothesized that indigenous competence is not limited to rural areas, but is also expanding across urban areas as it is also present in every culture which has built up a body of knowledge over several generations (Subba Rao, 2006).

In African countries, it is an old proverb that when an knowledgeable elder dies, an entire library is destroyed in the process (Grenier, 1998) on account of cultural wisdom comprising the important information which has come from the representational experience of the people over many centuries. The knowledge received by indigenous peoples to their survivors is not documented in any form, but includes insights into the management of the environment and biodiversity (Warren, 1992).

The most promising path for economic growth amongst indigenous communities was promoted as entrepreneurship among indigenous communities (Fuller et al., 2003). The indigenous entrepreneurs are typically faced with problems that are, in particular, lack of access to loans and financial assistance, insufficient business preparation, low demand for goods, market exclusion and conventional lenders; limited resources and lack of necessary financial and corporate management skills (Sarkar S, 1996). Indigenous entrepreneurs are also considered higher risk by traditional lenders due to inadequate cash flow which is also the key barrier. Often the expense of non-financial resources exceeds the revenue from the loan. The lack of sufficient control over natural resources and the corruption and incompetency within the tribal governance is also one of the major factors for non development of the indigenous entrepreneurship.

\subsection{History of Dokra Crafts}

Dokra is one of the oldest Indian craft of indigenous people who are discovering urban lifestyles and cultures (Kochhar, R., 2001). The art of dokra is the lost metal casting wax casting process, which is primitive in the Indus valley's 5000-year-old past. This art is considered popular as it has a broad cultural connection among communities with a folk charisma (Sen, D., 1963). This Dockra craft has, for many centuries, been connected to India's tribal culture, particularly in central India, because of the area rich in metals.

Ruth Reeves (1962) carried out the first comprehensive cire deficiency analysis in the Bankura district in the early 1960s. It was the prime basis for many later studies and doctoral research (e.g. Krishnan, 1976; Pal, 1978). There has never 
been a comprehensive audio visual archive of the craft, however, and this article is intended to fill this void. This records a time in which the Bikna people adapt their conventional methods of operating to the demands and possibilities of a modern technology as well as a changing economic climate.

Once prevalent in India, Dokra's ancient art or missing wax metal cast was now limited to a few groups of traditional craftsmen in prevalent regions. The Central and Eastern Indean Doco migrated south to Andhra Pradesh and north to Rajasthan a few hundred years ago and has now been found all over India. The tribe that extends from Jharkhand to West Bengal and Orissa is considered as far-off cousins of the Chhattisgarh Dokras. The most prominent Dokra pockets are Bastar in the Andhra Pradesh, Puri, Mayurbhani, and Khurda districts of Adilabad in Orissa, Puri, Burdwan, Bankura and Midnapore, and semi-tribal groups of the Vindhya mountains.

The Dokra name was once used by nomadic artisans to label a group of beautifully crafted and adorned brass items that have been made by a lost wax process. The mark Dokra is also wide-ranging (Kochhar, 2001). The art of casting lost wax is old in India and seems to have persisted in an unparalleled tradition from the beginning of developed civilization in the subcontinent. Such cast-metal statues (Kochhar, 2001) are typically dedicated to depictions of the gods and deities of Hindu and Tribus, plates, characters or deities riding elephants, singers, horse and rider figures, elephants and bovines, and other people's, animals and birds figures. In recent years (Sen, 1994), they have been compelled to diversify their items under pressure of all-encompassing industrialization and modified social standards, by losing their traditional rural market and are now searching for a niche for urban sophisticates, with the aid of government and some voluntary organizations, as producers of decorative goods. Such attempts have been really successful (Sen, 1994).

\subsection{The Dokra Artisans}

The most prominent bronze "dancing child," located in Mohenjo-Daro in the Indus Valley (Agrawal, 1971), is the earliest known examples from cire loss works. A elegant bronze figure even at such an early stage demonstrates already the rapidly emerging ingenuity and skillfulness of the manufacturing method characteristic of the loss of cire (kochhar, 2001). The Dokra craft community has been called Ghadwa, and they are a group of handicraftsmen who supply the villagers with daily utensils crafted from brass and other metals. Chhattisgarh's artisans say that their ancestors were tribal and emigrated from Maharashtra to Bastar some hundred years ago. The king of Bastar had given his beloved wife a Dokra art collar around 3000 years earlier. He was pleased to see the mask. He honoured craftsmen with the name "Ghadwa" to bear witness to the elegance of the shirt (Singh, K.S., 1993). The name Ghadwa was derived from the word Ghalna which means wax. The term Ghadna means the process of creation and development. It is also derived from. Also popular in other regions of India are Vishwakarmas, Ghasias, Mangan and Kansara (Kochhar, 2001).

Since the Indus Valley period until this modern age, a group of nomads have studied this craft successfully. The method of thought, attitude, shape and appeal have been changed, but the style is similar. The product of this exchange was mainly idolized, but slowly, the artisans began to enter the market with new designs, due to changing times and the access to current fashion. The production of decorative goods also has expanded the demand for specialized urban consumers and exports. Greedy traders and intermediates of handicrafts took advantage of the lack of sufficient quality control for the commodity by the State and the charitable association (Postel \& Cooper, 1999).

\subsection{Profile of Dokra Workers of Bikana and Dariapur villages}

Dokra craft is located in Bikana Village of the district of Bankura and nearby Dariyapur Village of the district of Burdwan 
in West Bengal, among related communities (Kochhar, 2001). The tribes of Dokra Damar are the main metal smiths of West Bengal and their wax casting technique is named after that tribe. The custom derives from the ancient half-nomadic tribes of Bastar called Dokras, Madhya Pradesh. A few Dokra families moved from Bastar to Bengal's alluvial plains, settling in Bankura in Dariapur, and Bikana in Burdwan. Many groups in the Dokra region are incredibly poor and have been abandoned by many families to provide wage labor in local manufacturing centers or metropolitan areas such as Kolkata (Kochhar, 2001), owing to their economic conditions. As per the 2011 census, the population of Dariapur village of Burdwan district is 3078 and the total number of house is 782, out of which, 42 families belongs to Dokra craftsman. The Bikana village of Bankura district is having 914 houses with population of 3784 as per the 2011 census. There are 56 families engaged in dokra manufacturing activities.

Dariapur and Bikana's dokra workers are well-known and settled here in 1962. Earlier it was known as Malars or Mals but now it is known as Karmakar or Dokra Kamars. Ghatra Kamars is named by dokra staff making and fixing kitchens and household utensils. They are landless people and come under the group of other castes. While they are weak in financial circumstances, they are listed as APL (Above Poverty Line) group by caste element (Sen, 1994). The development process involves both men and women. Their native language is Malhar (district Bastar language) and they are of the Hindu faith and the Bengali people are like food, clothes, shelter and marriage structures. The Dokras are probably the most active and innovative craft community in West Bengal. But over the past few years, with the support of the government and other charitable organisations, they have diversified their offerings into a new artistic art (Sen 1994).

There is definitely a lot of uncertainty when anyone seek to trace the Bikna family's ancestors through the data from the Bengal pre-independence census. Mitra (1953. p.2) has demonstrated that the census results continue to raise or eliminate caste designations, which leads to an seemingly arbitrary grouping and the resulting disintegration of "caste" classes. Kocchar (2001) wrote that financial support for Dhokra craftmen should ensure that the standard of the work, innovation and heritage are cheerfully passed to the next generation for continuity and development, not as a charity but a reasonable price for their goods.

\section{PURPOSE OF THE STUDY}

The key objectives of the study is to explore accessibility and save the ancient indigenous technologies used by these workers with financial capital for sustainable production by dokra craftspeople.

\section{STATEMENT OF THE PROBLEM}

The dokra artisans are confined to the Bikana village of Bankura district and nearby Dariapur village of Burdwan district in West Bengal where total 98 families are engaged in dokra manufacturing activities but these craftsman are the poorest among all other type of crafts man (Sen, 1994) and as they are not banking in the absence of proper protection which, by the use of private networks like money landers, lets these crafts people meet their financial requirements at a very high interest rate which causes debt and traps them into a vicious debt loop. There are other non-financial challenges like health hazards due to the poor work environment, engagement of child labour, lack of market accessibility which makes a big question mark on the survival of dokra artisans.

\section{OBJECTIVE OF THE STUDY}

The study has the following objectives: 
- To find out whether the dokra artisan approach to the bank for financial help for survival of their technology \& Bank has given assurance for financial help to dokra artisan

- To find out whether the dokra artisan has submitted the application to the bank for availing the loan \& the status of the acceptance of their application for further processing to grant the loan.

- Whether the dokra artisan can arrange to provide security or third party guarantee for availing the loan and Bank has agreed to give loan without any security or third party guarantee

- To observe the living condition of the family members of these artisan

- To check the kind of health epidemic these craftsmen are facing and the action taken to tackle the disease.

- To search the position of income and saving of the dokra family

- To find out the other basic problems facing by these dokra family

Based on the above objective the following hypothesis have been framed for the study:

H0: There is no significant difference between the expectation of dokra artisan and actual delivery of finance assistant from the bank for sustaining of the dokra technology in the state of West Bengal

H1: There is a significant difference between the expectation of dokra artisan and actual delivery of finance assistant from the bank for sustaining of the dokra technology in the state of West Bengal

\section{Operative Hypothesis no 1}

\section{Null Hypothesis 1}

H0:1 The bank has not given assurance to dokra artisan for providing financial assistant for sustaining of the dokra technology in the state of West Bengal

\section{Alternative Hypothesis 1}

H1:1 The bank has given assurance to dokra artisan for providing financial assistant for sustaining of the dokra technology in the state of West Bengal

Operative Hypothesis no 2

\section{Null Hypothesis 2}

H0:2 There is no significant difference between actual acceptance of loan applications by the bank as submitted by the dokra artisan for seeking the financial assistant for sustaining of the dokra technology in the state of West Bengal

\section{Alternative Hypothesis 2}

H1:2 There is a significant difference between actual acceptance of loan applications by the bank as submitted by the dokra artisan for seeking the financial assistant for sustaining of the dokra technology in the state of West Bengal

\section{Operative Hypothesis no 3}

\section{Null Hypothesis 3}

H0:3 : Bank has not agree to give loan without any security or third party guarantee 


\section{Alternative Hypothesis 3}

H1:3 : Bank has not agree to give loan without any security or third party guarantee

\section{METHODOLOGY}

\subsection{Population}

The population for the study comprises of 50 households with 25 households drawn from Dariapur village of Burdwan district and Bikana village of Bankura district respectively comprising respondents of Dokra artists.

\subsection{Data Collection}

Data used for the study have been collected from primary source through the use of personal interview schedule. The head of the family was taken as the primary representative from among the household members of Dokra artists while collecting information. Semi-structured questionnaire and interviews has been used as a tool to elicit information about the various dimension of literacy, income, savings, financial assistance and condition of dwelling house, health problems and also the problems related to the business in the field of marketing of the product, raw materials and training. The other part of the questionnaires is related to the approaching for the bank loan and the position of the financialassiatant by the bank. All relevant data collected were tabulated and analysis drawn thereon.

\section{ANALYSIS}

\subsection{Analysis of data for Hypothesis -1}

\section{Null Hypothesis}

H0 The bank has not given assurance to dokra artisan for providing financial assistant for sustaining of the dokra technology in the state of West Bengal

Alternative Hypothesis H1 : The bank has given assurance to dokra artisan for providing financial assistant for sustaining of the dokra technology in the state of West Bengal

Table 1: Chi-Square Tests

\begin{tabular}{|l|c|c|c|c|c|}
\hline & Value & df & $\begin{array}{c}\text { Asymp. Sig (2- } \\
\text { Sided) }\end{array}$ & $\begin{array}{c}\text { Exact Sig. (2- } \\
\text { Sided) }\end{array}$ & $\begin{array}{c}\text { Exact Sig (1- } \\
\text { sided) }\end{array}$ \\
\hline $\begin{array}{l}\text { Pearson Chi } \\
\text { Square }\end{array}$ & $8.104^{\mathrm{a}}$ & 1 & .004 & & \\
\hline $\begin{array}{l}\text { Continuity } \\
\text { Correction }\end{array}$ & 6.438 & 1 & .011 & & \\
\hline $\begin{array}{l}\text { Likelihood } \\
\text { ratio }\end{array}$ & 8.128 & 1 & .004 & & .006 \\
\hline $\begin{array}{l}\text { Fisher's } \\
\text { Exact Test }\end{array}$ & & 1 & .005 & & \\
\hline $\begin{array}{l}\text { Linear by } \\
\text { Linear } \\
\text { Association }\end{array}$ & 7.941 & & & & \\
\hline $\begin{array}{l}\text { Nof Valid } \\
\text { Cases }\end{array}$ & 50 & & & & \\
\hline
\end{tabular}

a. 0 cells $(.0 \%)$ have expected count less than 5. The minimum expected count is 6.40 .

b. Computed only for a $2 \times 2$ table 

Survival of their Indigenous Technology - A Study of West Bengal, India

From Chi-Square Tests (Table- 1) the degree of freedom is 1 and the corresponding p- value is .004 which is less than the level of significance at 0.05 . P value is rejected hence we fail to accept the null hypothesis and alternate hypothesis is accepte.

Interpretation: The bank has given assurance to the dokra artisan for financial help when they approache the bank.

\subsection{Analysis of data for Hypothesis -2}

\section{Null Hypothesis 2}

H0:2 There is no significant difference between actual acceptance of loan applications by the bank as submitted by the dokra artisan for seeking the financial assistant for sustaining of the dokra technology in the state of West Bengal

\section{Alternative Hypothesis 2}

H1:2 There is a significant difference between actual acceptance of loan applications by the bank as submitted by the dokra artisan for seeking the financial assistant for sustaining of the dokra technology in the state of West Bengal .

Table 2: Chi-Square Tests

\begin{tabular}{|l|c|c|c|c|c|}
\hline & Value & df & $\begin{array}{c}\text { Asymp. Sig (2- } \\
\text { Sided) }\end{array}$ & $\begin{array}{c}\text { Exact Sig. (2- } \\
\text { Sided) }\end{array}$ & $\begin{array}{c}\text { Exact Sig (1- } \\
\text { sided) }\end{array}$ \\
\hline $\begin{array}{l}\text { Pearson Chi } \\
\text { Square }\end{array}$ & $.205 \mathrm{a}$ & 1 & .651 & & \\
\hline $\begin{array}{l}\text { Continuity } \\
\text { Correctionb }\end{array}$ & .000 & 1 & 1.000 & & .641 \\
\hline Likelihood ratio & .194 & 1 & .659 & & .487 \\
\hline $\begin{array}{l}\text { Fisher's Exact } \\
\text { Test }\end{array}$ & & & & .654 & \\
\hline $\begin{array}{l}\text { Linear by Linear } \\
\text { Association }\end{array}$ & .201 & 1 & & & \\
\hline N of Valid Cases & 50 & & & & \\
\hline
\end{tabular}

a. 1 cells (25.0\%) have expected count less than 5 . The minimum expected count is 1.54 .

b. Computed only for a $2 \times 2$ table

From Chi-Square Tests (Table -2) the degree of freedom is 1 and the corresponding p- value is .641 (Fisher's Exact Test) which is greater than the level of significance at 0.05 . $\mathrm{P}$ value is accepted hence we fail to reject the null hypothesis and alternate hypothesis is rejected.

Interpretation: The bank has accepted the application submitted by the dokra artisan for granting of the loan for survival of their indigenous dokra technology.

\subsection{Analysis of data for Hypothesis -3}

\section{Null Hypothesis 3}

H0:3 : Bank has not agree to give loan without any security or third party guarantee

\section{Alternative Hypothesis 3}

H1:3 : Bank has not agree to give loan without any security or third party guarantee 
Table 3: Chi-Square Tests

\begin{tabular}{|l|l|l|l|l|l|}
\hline & \multicolumn{1}{|c|}{ Value } & \multicolumn{1}{c|}{ df } & $\begin{array}{c}\text { Asymp. Sig (2- } \\
\text { Sided) }\end{array}$ & $\begin{array}{c}\text { Exact Sig. (2- } \\
\text { Sided) }\end{array}$ & $\begin{array}{c}\text { Exact Sig (1- } \\
\text { sided) }\end{array}$ \\
\hline $\begin{array}{l}\text { Pearson Chi } \\
\text { Square }\end{array}$ & $.758 \mathrm{a}$ & 1 & .384 & & \\
\hline $\begin{array}{l}\text { Continuity } \\
\text { Correctionb }\end{array}$ & .107 & 1 & .744 & & \\
\hline Likelihood ratio & .678 & 1 & .410 & & .344 \\
\hline $\begin{array}{l}\text { Fisher's Exact } \\
\text { Test }\end{array}$ & & & & .586 & \\
\hline $\begin{array}{l}\text { Linear by Linear } \\
\text { Association }\end{array}$ & .742 & 1 & .389 & & \\
\hline N of Valid Cases & 50 & & & & \\
\hline
\end{tabular}

a. 2 cells $(50.0 \%)$ have expected count less than 5 . The minimum expected count is 1.20.

b. Computed only for a $2 \times 2$ table

From Chi-Square Tests (Table -3) the degree of freedom is 1 and the corresponding p- value is .586 (Fisher's Exact Test) which is greater than the level of significance at $0.05 . \mathrm{P}$ value is accepted hence we fail to reject the null hypothesis and alternate hypothesis is rejected

Interpretation: Bank has not agree to give loan without any security or third party guarantee as expected by the dokra artisans.

\subsection{Tabulation of Data}

The collected information through the interview schedule has been tabulated with the following outcomes:

Table 4: Profile of Dokra Family

\begin{tabular}{|l|l|l|l|l|l|l|}
\hline S.No & $\begin{array}{l}\text { Population Size of } \\
\text { Family }\end{array}$ & $\begin{array}{l}\text { No. of } \\
\text { Family }\end{array}$ & $\begin{array}{l}\text { Total Workers } \\
\text { in Family }\end{array}$ & $\begin{array}{l}\text { No of Female } \\
\text { Workers }\end{array}$ & $\begin{array}{l}\text { No of Male } \\
\text { Workers }\end{array}$ & $\begin{array}{l}\text { No.of Child } \\
\text { Worker }(>\mathbf{1 0} \\
\text { yrs) }\end{array}$ \\
\hline 1 & 2 to 3 & $11(22 \%)$ & $23(9 \%)$ & $11(48 \%)$ & $8(35 \%)$ & $4(17 \%)$ \\
\hline 2 & 4 to 6 & $27(54 \%)$ & $106(41 \%)$ & $32(30 \%)$ & $25(24 \%)$ & $49(46 \%)$ \\
\hline 3 & 7 to 10 & $12(24 \%)$ & $129(50 \%)$ & $41(32 \%)$ & $29(22 \%)$ & $59(46 \%)$ \\
\hline & Total & 50 & 258 & $84(33 \%)$ & $62(24 \%)$ & $112(43 \%)$ \\
\hline
\end{tabular}

Source: Survey Data

Observation: The data reveals that as the household size increases participation rate of female workers and child worker increases. This is because of the fact that an increased household demands more number of working people to maintain the standard of living. In most of the cases, the children are not going to school as the parents are engaging them into income generating activities.

Table 5: Literacy of the Workers:

\begin{tabular}{|l|l|l|l|l|}
\hline S.No & \multicolumn{1}{|c|}{ Category } & No. of Workers & Literacy & \% of Literacy \\
\hline 1 & Female Workers & 84 & 31 & 37 \\
\hline 2 & Male Workers & 62 & 38 & 61 \\
\hline 3 & Child Workers & 112 & $83 *$ & 74 \\
\hline & Total & 258 & 122 & 48 \\
\hline
\end{tabular}

* includes school going children Source: Survey Data

Observation: The above table shows literacy rate is more among the male workers as compared to female workers. The 
literacy rate is more among the child workers but this is basically primary education, most of them are not joining in higher education due to lack of income in the household.

Table 6: Health Status

\begin{tabular}{|l|l|l|l|l|l|l|l|l|}
\hline S.No & \multicolumn{1}{|c|}{ Diseases } & Female & \multicolumn{1}{c}{$\%$} & \multicolumn{1}{|c|}{ Male } & \multicolumn{1}{|c|}{ Child } & \multicolumn{1}{|c|}{ Total } & \multicolumn{1}{|c|}{ Tot } \\
\hline 1 & Breathing Problem / Asthma & 19 & 23 & 18 & 29 & 15 & 13 & $52(20 \%)$ \\
\hline 2 & Headache & 12 & 14 & 6 & 9 & 3 & 3 & $21(8 \%)$ \\
\hline 3 & T B & 14 & 17 & 12 & 19 & 12 & 11 & $38(15 \%)$ \\
\hline 4 & Visual Problem & 9 & 11 & 8 & 13 & 2 & 2 & $19(7 \%)$ \\
\hline 5 & Skin Deceases & 7 & 8 & 4 & 6 & 6 & 5 & $17(6 \%)$ \\
\hline 6 & Others & 3 & 4 & 5 & 8 & 11 & 10 & $19(7 \%)$ \\
\hline & Total & 64 & 77 & 53 & 84 & 49 & 44 & $166(64 \%)$ \\
\hline 7 & More than one Disease & 31 & 48 & 33 & 62 & 21 & 42 & $85(51 \%)$ \\
\hline 8 & Under Treatment & 25 & 39 & 26 & 49 & 36 & 73 & $87(52 \%)$ \\
\hline
\end{tabular}

Source: Survey Data

Observation: Most of the workers are suffering from various dieseases. This is due to the fact that they do not have adequate access to healthcare facilities. This is also another major area of concern as access to basic healthcare facilities should be made available to these people of study area.

Table 7: Monthly Family Income:

\begin{tabular}{|l|l|l|l|}
\hline S.No & \multicolumn{1}{|c|}{ Range of Income } & \multicolumn{1}{|c|}{ Number of Family } & \multicolumn{1}{c|}{$\%$} \\
\hline 1 & Below 5000/- & 12 & 24 \\
\hline 2 & $5000 /-$ to 8000/- & 22 & 44 \\
\hline 3 & $8001 /-$ to 10000/- & 10 & 20 \\
\hline 4 & $10001 /-$ and above & 6 & 12 \\
\hline & Total & 50 & 100 \\
\hline
\end{tabular}

Source: Survey Data

Observation: The data reveals that around $44 \%$ of the family members participated in the study having monthly family income in the range Rs. 5000 to Rs. 8000. If we consider average family size of 7 to 10 members per family, this income surely not sufficient to maintain basic standard of living. Most of the time, because of this low income, they do not have adequate access to basic facilities like healthcare and education.

Table 8: Family Saving Per Month

\begin{tabular}{|l|l|l|l|}
\hline S.No & \multicolumn{1}{|c|}{ Range of Savings } & Number of Family & \multicolumn{1}{c|}{$\%$} \\
\hline 1 & No Saving & 27 & 54 \\
\hline 2 & Less than 500/- & 16 & 32 \\
\hline 3 & $501 /-$ to $1000 /-$ & 4 & 8 \\
\hline 4 & Above 1000/- & 3 & 6 \\
\hline & Total & 50 & 100 \\
\hline
\end{tabular}

Source: Survey Data

Observation: The data reveals that most of the households do not have any savings and it is obvious as they do not have sufficient income to do so. Around 54\% of the family members participated in the study do not have savings. Rest of the family members have very limited savings per month. Lack of disposable income often restricts them not to spend more and on the other hand it is also reducing their savings for future survival when they will not be in a position to earn. Hence, increases the chance of vulnerability. 
Table 9: Financial Assistance

\begin{tabular}{|l|l|l|l|}
\hline S.No & \multicolumn{1}{|c|}{ Sources } & \multicolumn{1}{|c|}{ No of Family } & \multicolumn{1}{c|}{$\%$} \\
\hline 1 & From Bank & 4 & 8 \\
\hline 2 & From Private Money Mender Interest. 8-10\% $(\mathrm{pm})$ & 56 \\
\hline 3 & Loan from Local Purchaser & 28 & 26 \\
\hline 4 & No Loan & 13 & 10 \\
\hline & Total & 5 & 100 \\
\hline
\end{tabular}

Source: Survey data

Observation: Though, lots of efforts are implemented by the government to provide them financial assistance, that may not be the case in reality. The study suggests that around $56 \%$ of the respondents still depends on money lenders as they are easily available and accessaibility is more. Though, banking system is there, still the documentation and accomplishment is a major problem for these artisan families in the study area.

Table 10: Very Basic Problem Areas

\begin{tabular}{|l|l|l|l|l|}
\hline S.No & \multicolumn{1}{|c|}{ Area of Basic Problems } & \multicolumn{1}{|c|}{$\begin{array}{c}\text { No. of } \\
\text { Families } \\
\text { Agreed }\end{array}$} & \multicolumn{1}{|c|}{$\begin{array}{c}\text { Status of } \\
\text { Problems } \\
\text { ( Rank ) }\end{array}$} \\
\hline 1 & Increasing Price of Raw Material \& Fuel. & 41 & 82 & 5 \\
\hline 2 & Lack of Help from Govt. & 46 & 92 & 2 \\
\hline 3 & Lack of Financial Assistant at Low Interest. & 50 & 100 & 1 \\
\hline 4 & $\begin{array}{l}\text { Unaware of Market and Non Reachable to the Real } \\
\text { Customer. }\end{array}$ & 39 & 78 & 6 \\
\hline 5 & Exploitation by Middle Man. & 42 & 84 & 4 \\
\hline 6 & Lack of Training for Modern Technology. & 28 & 56 & 7 \\
\hline 7 & Lack of Advertisement, Sale Promotion and Exhibition. & 13 & 26 & 8 \\
\hline 8 & Various Physical Problems and Lack of Medical Treatment. & 45 & 90 & 3 \\
\hline
\end{tabular}

Source: Survey Data

Observation: Here the respondents were asked to give a rating out of the 8 factors in a scale of 1 to 8 , where 1 is most acute problem and 8 is not so acute problem. It is a fact that lack of financial assistance at a lower interest rate is a major problem revealed by the respondents. It is also interesting to see that they do not have any problem regarding advertisement, sales promotion and exhibition. Government took intenstive measures through its implementing agency to organize fairs and exhibitions on a periodic basis which gave them adequate exposure. But, capital requirement to produce the finished product and to purchase the raw materials is still a major problem.

\section{FINDINGS}

The findings of the study have been analyzed in the following paragraphs:

\section{Finding for objective no-1}

1) The dokra artisan approaches the bank for financial help and bank assured to help them as shown in the study.

\section{Finding for objective no-2}

2) The dokra artisan submitted the application in the bank with expectation to get the loan and bank has accepted their application for further processing to grant the loan.

\section{Finding for objective no-3}

3) Though the bank has accepted the applications from the dokra artisans and assure to dokra artisan for financial help but 
bank is not agreed to give loan without any security or third party guarantee to the dokra artisans.

\section{Finding for objective no 4 to 7}

- Family size and literacy: It is evident from Table $4 \& 5$ that $54 \%$ of the households have 4 to 6 member family size. The total numbers of female workers (33\%) are more than the male workers (24\%). The possible cause for this situation is the early death of male members due to poor life style habits like alcoholic nature and attack of various diseases. The child workers are more than the adult male and female workers. The children go to school as well as help the family members in the art craft.

- The literacy rate is $48 \%$ and male workers are more literate than female workers. The literacy among the child workers in these families is also impressive (74\%) which shows a positive sign due to school facilities in nearby villages.

- Health condition: The Dokra families are facing various health problems due to the nature of work (Table-6) as $64 \%$ of the total workers are suffering from some diseases, out of which $51 \%$ are suffering from multiple disease and $52 \%$ are under treatment. $77 \%$ of female and $84 \%$ of male workers are having health problem where as the various diseases amongst the child workers are less (44\%). It is also evident that the problem of breathing, asthma, cold etc is major one (20\%) besides T.B. (15\%) out of total patients. Pollution by dust, smoke etc are the main cause behind the asthma and staying of long working period in heat, smoke and the habit of alcohol taking is the main cause of T.B as well as headache. We can also observe from Table-10 that the various physical problems and lack of medical treatment is one of the basic problems for the Dokra workers.

- Financial condition: It is evident from Table-4 that the maximum family (44\%) is earning monthly income between ₹ 5000/- to ₹ 8000/- and only 12\% of Dokra family is earning more than ₹ 10000/- per month. The savings of these families is also very poor as $54 \%$ of the households are not having any form of savings; where as $32 \%$ of family is saving less than ₹ 500/- per month (Table-8). Taking of loan from various sources is a common feature as $95 \%$ of Dokra workers are indebted and $56 \%$ of Dokra family have taken loan from private money lender with a high interest of $8 \%$ to $10 \%$ per month (Table-9). Lack of savings and financial crisis forced them to take loan from money lenders as well as from the purchaser / order supplier of Dokra crafts.

- Basic Problem: Almost all the family are facing the problem of lack of financial assistance at low interest (Table 10) beside the lack of government help to the Dokra families. $90 \%$ of the families opine that the health hazards and lack of proper treatment is one of the major problems facing them. The exploitation by the agents or middle man is also a major problem for the Dokra artisans as they take the advantage of poor financial condition of these artisans as well as the non recognition of the actual customer of the product.

\section{CONCLUSIONS}

Dokra products both locally and globally have tremendous appeal, consumer recognition and craze. Most artisans, however, have no idea about marketing platforms and are not immune to public demand. A a few craftsmen from the entire company succeeded in integrating their goods with the real customers. They get orders from local suppliers and get simple work completed at cheap prices by other fellow craftspeople. Many craftsmen can not benefit significantly from their goods. However, the craftsmen take loans from local grocery stores to cover their household costs and often even sell the 
material and take the credit with a fixed interest on objects' mortgage. If the artisan fails to repay the loan, the mortgage items become the items of sale in the grocery shop and sometime the shop owners supplies the products to Delhi and Mumbai as his side business. The government is also reluctant to frame an effective policy to develop the condition of these artisans. A majority of the artisans are under the clutches of money lender due to the lack of bank finance as these artisans are treated as non bankable by the bankers. Due to lack of sufficient income, the workers are migrated to nearby cities in search of job.

The Dokra craftsmen of West Bengal have been in continuous development for centuries and represent an old art. Such craftsmen are not 'primitive,' but they are people of the 21 st century caught in a process of misery. They must be able to settle about their own future, while simultaneously encompassing multiple centuries of experience, which is not only part of India's cultural heritage but also of humanity. This would be devastating that all this experience and the cumulative wisdom of centuries becomes forgotten in whatever path the art takes in the future.

\section{REFERENCES}

1. Arthur, W.S. (1999). What's New: The 1997parliamentary Inquiry into Indigenous Business. Centre for Aboriginal Economic Policy Research Discussion Paper No. 177. Canberra: CAEPR, Australian National University

2. Dahlman, P, \& Atteh O.A. (1989). "Indigenous Local Knowledge as Key to Local Level Development Possibilities, Constraints and Planning Issues in the Context of Africa."

3. Fuller, D., Howard, M. \& Cummings, E. (2003). Indigenous Micro-Enterprise Development in Northern Australia Implications for Economic and Social Policy. Journal of Economic and Social Policy, 1 (2): 15-34.

4. Grenier, L. 1998. Working with Indigenous Knowledge: A guide for researchers: International Development Research Centre. Ottawa, ON, Canada

5. Guin, Debarshi, (2013), Marketing of Dokra Handicrafts and Livelihood status of the Artisans: A case study of Bankura District, Indian Journal of Landscape systems and Ecological studies, 36(1), 258-264.

6. Holt, D. (1997). A Comparative Study of Values Among Chinese and U.S. Entrepreneurs: Pragmatic Convergence Between Contrasting Cultures. Journal of Business Venturing, 12 (6): 484-490.

7. Kochhar, R (2001). Dokra brass artefacts from Bankura Pamphlet published for CSIR Foundation Day, 2001. NISTADS, New Delhi.

8. Mitra, A (1953). The Tribes and Castes of West Bengal. Census of India 1951: West Bengal. West Bengal Government Press, Alipore.

9. Postel, $M \&$ Cooper, Z (1999). Bastar Folk Art: Shrines, Figurines and Memorials. Project for Indian Cultural Studies Publication VIII, Mumbai.

10. Sarkar, S (1996) The changing face of the craftsman: Blacksmith in colonial Jharkand. Calcutta Historical Journal 18 (2)pp. 67-85.

11. Sarkar, S (1998) Indian craft-technology: static or changing - a case study of the Kansari's craft in Bengal, 16th to 18th Centuries. Indian Journal of History of Science, 33 (2) pp. 131-142.

12. Sen, D., Ghosh, A.K. and Chatterjee, M., Palaeolithic Industry of Bankura, West Bengal, Vol.. 43, 1963.

13. Sen, P. (1994) Crafts of West Bengal. Mapin Publishing, Ahmadabad.

14. Smith, DJ and Hall, J (2001) Multimedia know-how archiving in aviation industry training. In Proceedings of the 7th IFAC 
Symposium on Automation Based on Human Skill: Joint Design of Technology and Organisation ed. Brandt, D. and Cerenetic, J., Elesevier, Oxford.

15. Subba Rao, S. 2006. Indigenous knowledge organization: An Indian scenario. International Journal of Information Management, 26(3): 224-233.

16. Warren, D. M., \& Rajasekaran, B. 1993. Putting Local Knowledge to good Use. International Agricultural Development, 13(4): 8-10. 

